\title{
Variability in Nutritional Profile and Textural Properties of Differe nt Cuts of Lamb Meat from Subei Gansu
}

\author{
Hong Zhu ${ }^{1, *}$, Ju Qiu ${ }^{1}$, Ke-hong Liang ${ }^{1}$, and Jing Wang ${ }^{1}$ \\ ${ }^{1}$ Institute of Food and Nutrition Development, Ministry of Agriculture and Rural Affairs, 100081 Beijing China
}

\begin{abstract}
The nutritional profile and textural properties of Subei lamp from Gansu province, as an emerging area of high-quality lamp meat production area in northwest of China, were evaluated. Protein, lipid, amino acid, mineral content, vitamin content as well as texture character of nine different cuts from Subei lamp were determined. Significant difference was found in most nutrition components and textural traits. The protein content ranged from 7.71 to $29.50 \mathrm{~g} / 100 \mathrm{~g}$. The lipid content ranged from 2.18 to 11.95 $\mathrm{g} / 100 \mathrm{~g}$. Total amino acid content varied from 13.10 to $19.45 \mathrm{~g} / 100 \mathrm{~g}$, and content of l-carnitine was between 851.48 to $2019.91 \mathrm{mg} / \mathrm{kg}$. The $\mathrm{K}$ and Fe content ranged from 2797.50 to $3783.00 \mathrm{mg} / \mathrm{kg}$ and 10.73 to 20.44 $\mathrm{mg} / \mathrm{kg}$, respectively. The vitamin $\mathrm{B}_{2}$ content varied from 0.177 to $0.438 \mathrm{mg} / 100 \mathrm{~g}$; vitamin E content ranged from 0.201 to $0.438 \mathrm{mg} / 100 \mathrm{~g}$. The scope of vitamin $\mathrm{B}_{3}$ content was between 5.746 to $8.560 \mathrm{mg} / 100 \mathrm{~g}$, and Subei lamp was also a dietary source of folic acid, which ranged from 2.820 to $6.852 \mathrm{ug} / 100 \mathrm{~g}$. Short loin chop was considered as a high-quality lamp meat, as it was high in protein, vitamin E and low in lipid. Subei lamp considered are significant sources of $\mathrm{Fe}, \mathrm{Zn}$ and $\mathrm{K}$. Variations in nutritional profiles observed in various cuts of lamp can help the dietary assessment, and also the product's nutritional labelling.
\end{abstract}

\section{Introduction}

Lamp is one of the most popular red meats in the global market, which is estimated to be produced at around 14.326 million tons in 2015. Lamp's popularity can be attributed to its unique flavor and nutrition profile, which contains high quality protein, low fat and cholesterol content ${ }^{[1]}$. Gansu province, located in northwest of China, is also a main production area of lamp, after Inner Mongolia and Xinjiang province. Subei lamp was raised in north of Gansu province, and around $3000 \mathrm{~m}$ above sea level.

Although consumer attitudes to meat are influenced by a number of factors (price, availability, culture, etc.), in recent years information about nutrient composition (labelling) has become increasingly important, especially for health conscious consumers. Changes in nutrient composition that habitually occur in commercial lamp meat products in the course of different cuts need to be considered for purposes of production systems control, consumer safety, nutritional information, labelling, official regulations or quality of food composition databases. Many research has been done in order to find the cause of variation of nutrients in lamp production. The composition (e.g. fat content and composition, mineral content) of lamp is expected to reflect the variability of feeding management, animal characteristics (breed, age, sex, weight, etc.) and environmental conditions, which depend on cultural practices, season and geographical factors. In the last few years there have been reports of changes in the nutritional composition of red meat as determined by various different factors ${ }^{[2,3]}$. However, research about the change of nutrition profile of lamp meat due to various cuts was still limited.

This article focused variation of nutrition profile of different cuts of Subei lamp from Gansu province, as an emerging area of high-quality lamp meat production area in northwest of China. In addition, the texture character was also determined. Information from this study can help to dietary assessment, and also the product's nutritional labelling.

\section{Materials and Method}

\subsection{Sample preparation}

The Subei lamp were pastured together from Kangle grassland with an altitude of $3000 \mathrm{~m}$ from Gansu province in northwest of China. The six sheep (average liveweight $27.10 \pm 1.45 \mathrm{~kg}$ ) were randomly selected at the age of six months. All sheep were fed with the same diet and with the same genetic background. Before slaughtering the sheep, the sheep were transported to slaughter factory within $1 \mathrm{~h}$ and fasted for $24 \mathrm{~h}$. The sheep were slaughtered by severing the trachea, esophagus, carotid arteries in a local commercial abattoir. Square cut shoulder, breast and flap, topside, tripe, neck, tender loin, short loin chop, shoulder rack French, legchump off were obtained based on cutting technical specification of mutton (NY/T 1564-2007, The ministry

\footnotetext{
*Corresponding author: zhuhong@caas.cn
} 
of agriculture and rural affairs of the People's Republic of China, 2007). After chilling at $4{ }^{\circ} \mathrm{C}$ for $24 \mathrm{~h}$, the muscles from left carcass were quickly frozen by liquid nitrogen, stored at $-80{ }^{\circ} \mathrm{C}$ and used for analysis. The nine carcass cuts were wrapped with nylon/polyethylene $(9.3$ $\mathrm{mL} \mathrm{O} / \mathrm{m}^{2} / 24 \mathrm{~h}, 0{ }^{\circ} \mathrm{C}, 0.19 \mathrm{~mm}$ thick, Magic Seal ${ }^{\circledR}$, Guangdong, China). The samples were transported to Beijing by cold-chain logistics and the samples were maintained the low temperature by using dry ice. Frozen muscles were thawed at $4{ }^{\circ} \mathrm{C}$ for $12 \mathrm{~h}$, trimmed off connective tissue and visible fat, cut into cubes $(2 \times 2 \times 2$ $\mathrm{cm}^{3}$ ), and dry-cured at $4{ }^{\circ} \mathrm{C}$ for $6 \mathrm{~h}$ with $1 \%$ salt.

\subsection{Proximate analysis}

Levels of crude protein and lipid were determined according to the Association Official Analytical Chemists (AOAC) method. Crude protein content was estimated by determining the total nitrogen using the Kjeldahl method (AOAC, 2005a). Lipid content was analysed by the Soxhlet extraction method (AOAC, 2005b). Amino acid analysis was performed by the method of Carla Motta ${ }^{[4]}$. The amount of 1-carnitine present in food was estimated as described by McGarry and Foster (1976) ${ }^{[5]}$ modified by Galland, Le Borgne $(1998)^{[6]}$.

\subsection{Minerals}

Samples were ashed in triplicate in a furnace, with temperature gradients between 105 and $500{ }^{\circ} \mathrm{C}$. The ash was dissolved in $2 \mathrm{ml}$ concentrated nitric acid and diluted to $100 \mathrm{ml}$ with Milli-Q water. The minerals were determined on an atomic absorption spectrophotometer (Perkin-Elmer, Model 5100, Norwalk, Connecticut. USA). A hollow cathode lamp was used to determine $\mathrm{Ca}$, $\mathrm{Fe}, \mathrm{P}$, and $\mathrm{Se}$. $\mathrm{K}$ were analysed by atomic emission (without a lamp). Analytical lines were selected following the criterion of maximum sensitivity and were free of spectral interferences. The analytical curve was determined for each element using standard solutions (Panreac Química, S.A.U. Barcelona. Spain)

\subsection{Vitamins}

The vitamin $\mathrm{B}_{2}$ and $\mathrm{B}_{3}$ content was determined according to chromatographic HPLC methods EN 14152 ECS, 2014b (ECS Standard BS EN 14152:2014. European Committee for Standardization, Brussels, Belgium). The vitamin E content was determined according to a modification of the method of Katsanidis and Addis (1999) ${ }^{[7]}$ using normal phase HPLC. Tocopherols were extracted with hexane mixed with BHT. The analysis was carried out on a Merck liquid chromatograph with a fluorescence detector. The sample was injected onto a LUNA NH2 column $(250 \times 4.6 \mathrm{~mm})$ with a pre-column. Isocratic elution was carried out using a mixture of n-hexane and 2-propanol (95:5) at a flow rate of $2.5 \mathrm{~mL} / \mathrm{min}$. The wavelengths of excitation and emission were $290 \mathrm{~nm}$ and $330 \mathrm{~nm}$, respectively.
Folic acid quantification was according to the method of Daniela Andrade Neves ${ }^{[8]}$.

\subsection{Textural properties}

Textural properties of samples were evaluated using the Stable Micro System (Model TA.XT 2i/25 Surrey, U.K.). TPA was performed using central cores of two pieces of each sample $\left(1.5 \mathrm{~cm}^{3}\right)$, which were compressed twice to $60 \%$ of the original height. A crosshead speed of $2 \mathrm{~mm} / \mathrm{s}$ was used applying a $0.15 \mathrm{~N}$ load cell and $75 \mathrm{~mm}$ compression platen (P75).

\subsection{Statistical Analysis}

Values for various parameters were analysed by one-way analysis of variance (ANOVA) using the SPSS software for windows (version 19.0, SPSS, Inc., Chicago, IL). Comparisons of means were carried out by Duncan's multiple range test, considering significant differences when $\mathrm{P}<0.05$.

\section{Results and discussion}

\subsection{Proximate analysis}

The mean values of the protein, lipid, total amino acid and 1-carnitine for different cuts of Subei lamp are presented in Table 1. Significant difference was found in proximate analysis among different cuts of Subei lamp meat. The protein content ranged from 7.71 to 29.50 $\mathrm{g} / 100 \mathrm{~g}$, and the highest was found in short loin chop. Neck presented the lowest protein content. Sample also differed clearly in terms of the presence of lipids. The lipid content ranged from 2.18 to $11.95 \mathrm{~g} / 100 \mathrm{~g}$. Short loin chop presented the lowest lipid content. Total amino acid content varied from 13.10 to $19.45 \mathrm{~g} / 100 \mathrm{~g}$. The content of 1-carnitine was between 851.48 to 2019.91 $\mathrm{mg} / \mathrm{kg}$. The highest of 1-carnitine content was found in topside. In terms of preliminary component analysis, short loin chop was considered as a high-quality lamp meat, because it was high in protein and low in lipid. The highest variation was found in lipid content $(64.28 \%)$, and followed by protein $(37.18 \%)$, 1-carnitine $(20.11 \%)$ and total amnio acid $(11.74 \%)$.

L-carnitine is a vitamin-like substance and a nonprotein modified amino acid, which is mainly produced in the liver and kidney and vitamin $\mathrm{C}$, iron ions, and niacin play role in its production ${ }^{[9]}$. The main dietary sources of 1-carnitine are meat, fish and some other animal products such as milk ${ }^{[10]}$. This substance plays a major role in the oxidation of fatty acids in skeletal and cardiac muscle by transporting long-chain fatty acids into the mitochondria ${ }^{[11]}$. 
Table 1. Proximate analysis of nine cuts of Subei lamp

\begin{tabular}{lcccc}
\hline Cuts & $\begin{array}{l}\text { Protein } \\
(\mathrm{g} / 100 \mathrm{~g})\end{array}$ & $\begin{array}{l}\text { Lipid } \\
(\mathrm{g} / 100 \mathrm{~g})\end{array}$ & $\begin{array}{l}\text { Total amino acid } \\
(\mathrm{g} / 100 \mathrm{~g})\end{array}$ & $\begin{array}{l}\text { L-carnitine } \\
(\mathrm{mg} / \mathrm{kg})\end{array}$ \\
\hline Square cut shoulder & $15.70^{\mathrm{e}}$ & $5.08^{\mathrm{e}}$ & $17.65^{\mathrm{bc}}$ & $1788.74^{\mathrm{b}}$ \\
Breast and flap & $17.95^{\mathrm{d}}$ & $7.32^{\mathrm{c}}$ & $15.35^{\mathrm{d}}$ & $1595.68^{\mathrm{cd}}$ \\
Topside & $20.10^{\mathrm{b}}$ & $2.18^{\mathrm{h}}$ & $18.40^{\mathrm{b}}$ & $2019.91^{\mathrm{a}}$ \\
Tripe & $7.71^{\mathrm{g}}$ & $11.95^{\mathrm{a}}$ & $13.10^{\mathrm{e}}$ & $851.48^{\mathrm{f}}$ \\
Neck & $11.05^{\mathrm{f}}$ & $6.67^{\mathrm{d}}$ & $15.65^{\mathrm{d}}$ & $1768.90^{\mathrm{b}}$ \\
Tender loin & $20.60^{\mathrm{b}}$ & $3.16^{\mathrm{f}}$ & $17.00^{\mathrm{c}}$ & $1604.35^{\mathrm{c}}$ \\
Short loin chop & $29.50^{\mathrm{a}}$ & $2.26^{\mathrm{g}}$ & $19.45^{\mathrm{a}}$ & $1740.88^{\mathrm{b}}$ \\
Shoulder rack French & $18.80^{\mathrm{c}}$ & $10.37^{\mathrm{b}}$ & $14.85^{\mathrm{d}}$ & $1400.08^{\mathrm{e}}$ \\
Leg-chump off & $11.35^{\mathrm{f}}$ & $2.18^{\mathrm{h}}$ & $15.70^{\mathrm{d}}$ & $1531.10^{\mathrm{d}}$ \\
CV $(\%)$ & 37.18 & 62.48 & 11.74 & 20.11 \\
\hline
\end{tabular}
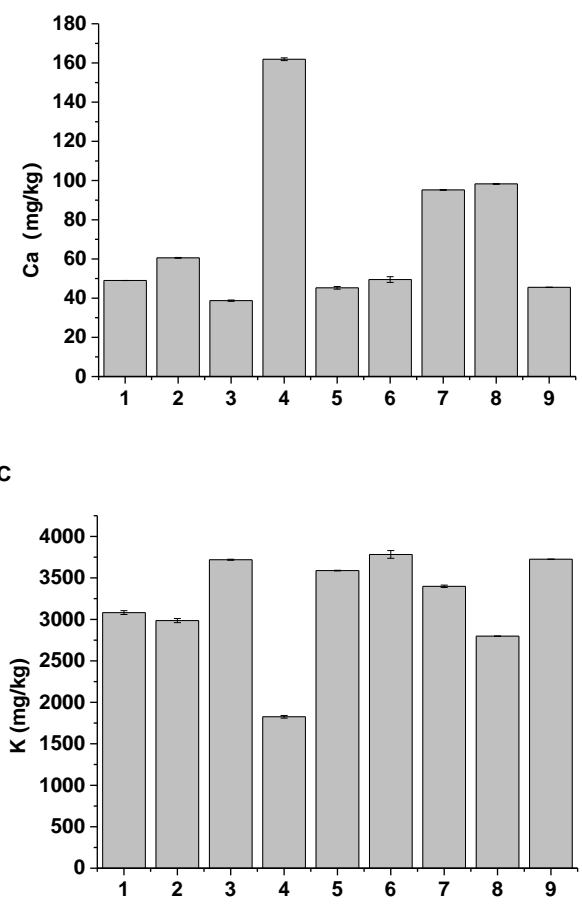
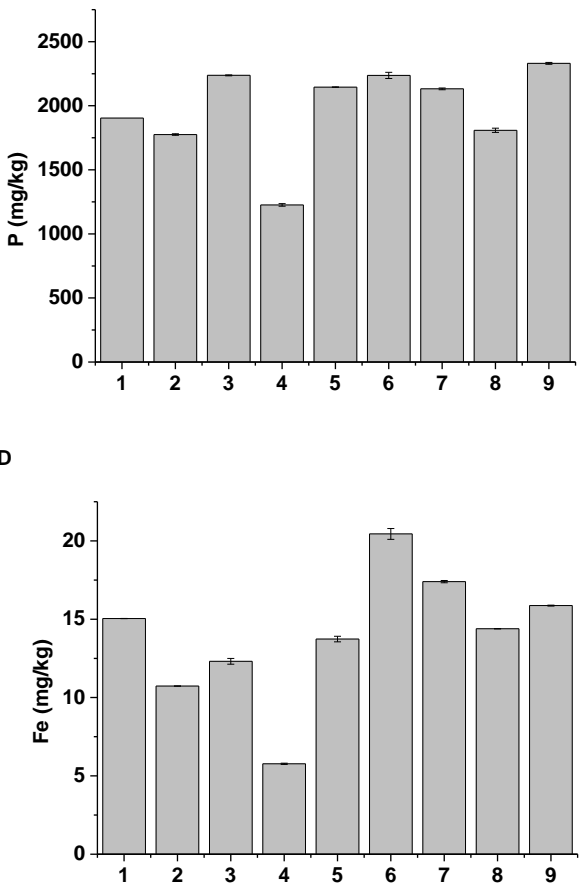

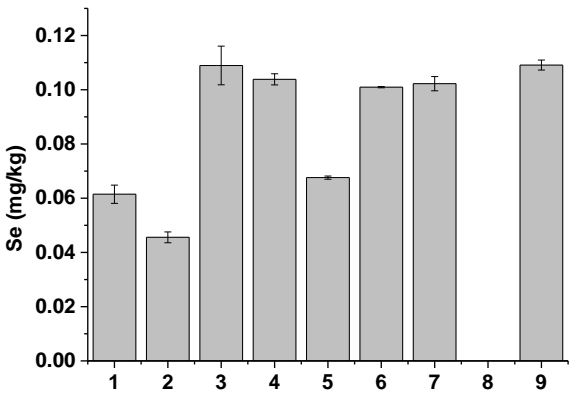

Fig. 1. Mineral content of different cuts of Subei lamp, A: Ca, B: P, C: K, D: Fe, E: Se. (1: square cut shoulder; 2: breast and flap; 3: topside; 4: tripe; 5: neck; 6: tender loin; 7: short loin chop; 8: shoulder rack French; 9: leg-chump off.) 


\subsection{Mineral}

A significant difference of mineral content of various cuts of Subei lamp was demonstrated in Fig. 1. The concentration of $\mathrm{Ca}$ varied widely in the sample analysed. Tripe, short loin chop, and shoulder rack French contained large amounts (around 95.25-161.90 mg/100g), while in all the other products contained roughly 2-4 times less, ranging from $38.72 \mathrm{mg} / 100 \mathrm{~g}$ in topside to $60.56 \mathrm{mg} / 100 \mathrm{~g}$ in breast and flap. Except for the tripe, where P levels was at $1226.00 \mathrm{mg} / 100 \mathrm{~g}$, the samples analysed all contained between 1775.50 and 2331.00 $\mathrm{mg} / 100 \mathrm{~g}$ of P. Similar trends were found in K and Fe content. The lowest content of both $\mathrm{K}$ and $\mathrm{Fe}$ were found in tripe. The $\mathrm{K}$ and $\mathrm{Fe}$ content ranged from 2797.50 to $3783.00 \mathrm{mg} / \mathrm{kg}$ and 10.73 to $20.44 \mathrm{mg} / \mathrm{kg}$, respectively. As for Se content, the highest value was presented in leg-chump off, followed by topside. Se was not detected in shoulder rack French. vitamin $\mathrm{B}_{3}$ (nicotinic acid) content was between 5.746 to $8.560 \mathrm{mg} / 100 \mathrm{~g}$, and most samples were in the same level. Subei lamp was also a dietary source of folic acid, which ranged from 2.820 to $6.852 \mathrm{ug} / 100 \mathrm{~g}$, and topside presented the highest level.

Our results were in agreement with previous study which indicated vitamin E concentration in lamp ranged from 2.53 to $5.06 \mathrm{mg} / \mathrm{kg}{ }^{[13]}$. According to this study, the content of vitamin $\mathrm{E}$ in lamp muscle was highly correlated to vitamin E content in dietary supplement of lamp. Folic acid is a synthetic water-soluble vitamin belonging to the folate group. This compound is essential to the human organism since it is involved in the metabolic reaction of carbon transfers, indispensable in the 'DNA biosynthesis cycle' and in the 'methylation cycle'. Folic acid deficiency is associated with neural tube defects, cardiovascular, cerebrovascular and neurodegenerative diseases, megaloblastic anemia and cancer $^{[14]}$

Table 2. Vitamin content of nine cuts of Subei lamp

\begin{tabular}{lllll}
\hline Cuts & $\begin{array}{l}\text { Vitamin } \mathrm{B}_{2} \\
(\mathrm{mg} / 100 \mathrm{~g})\end{array}$ & $\begin{array}{l}\text { Vitamin E } \\
(\mathrm{mg} / 100 \mathrm{~g})\end{array}$ & $\begin{array}{l}\text { Vitamin } \mathrm{B}_{3} \\
(\mathrm{mg} / 100 \mathrm{~g})\end{array}$ & $\begin{array}{l}\text { Folic acid } \\
(\text { ug/100g) }\end{array}$ \\
\hline Square cut shoulder & $0.438^{\mathrm{a}}$ & $0.788^{\mathrm{bc}}$ & $7.174^{\mathrm{ab}}$ & $2.820^{\mathrm{f}}$ \\
Breast and flap & $0.177^{\mathrm{h}}$ & $0.960^{\mathrm{b}}$ & $7.134^{\mathrm{ab}}$ & $2.420^{\mathrm{g}}$ \\
Topside & $0.312^{\mathrm{d}}$ & $0.515^{\mathrm{de}}$ & $5.746^{\mathrm{b}}$ & $6.825^{\mathrm{a}}$ \\
Tripe & $0.341^{\mathrm{c}}$ & $0.201^{\mathrm{f}}$ & $5.746^{\mathrm{b}}$ & $5.705^{\mathrm{d}}$ \\
Neck & $0.269^{\mathrm{f}}$ & $0.283^{\mathrm{ef}}$ & $6.500^{\mathrm{b}}$ & $5.605^{\mathrm{d}}$ \\
Tender loin & $0.371^{\mathrm{b}}$ & $0.496^{\mathrm{de}}$ & $6.574^{\mathrm{b}}$ & $5.845^{\mathrm{c}}$ \\
Short loin chop & $0.290^{\mathrm{e}}$ & $1.410^{\mathrm{a}}$ & $6.100^{\mathrm{b}}$ & $6.495^{\mathrm{b}}$ \\
Shoulder rack French & $0.267^{\mathrm{f}}$ & $0.630^{\mathrm{cd}}$ & $6.745^{\mathrm{b}}$ & $2.710^{\mathrm{f}}$ \\
Leg-chump off & $0.247^{\mathrm{g}}$ & $0.377^{\mathrm{def}}$ & $8.560^{\mathrm{a}}$ & $2.995^{\mathrm{e}}$ \\
\hline
\end{tabular}

Lamp meat is an important dietary source of bioavailable minerals and trace elements. Meat and meat derivatives are among the principal sources of dietary potassium, which plays an essential part in energy metabolism and membrane transport ${ }^{[12]}$. Iron deficiency produces anaemia, which is one of the principal public health problems.

\subsection{Vitamin}

The variation of vitamin content, namely vitamin $\mathrm{B}_{2}$, vitamin E, vitamin $\mathrm{B}_{3}$, and folic acid, were listed Table 2. Significant difference was found among different cuts of samples. The vitamin $\mathrm{B}_{2}$ content varied from 0.177 to $0.438 \mathrm{mg} / 100 \mathrm{~g}$, and the highest was found in square cut shoulder. Vitamin E content ranged from 0.201 to 0.438 $\mathrm{mg} / 100 \mathrm{~g}$ in nine cuts of Subei lamp. Short loin chop exhibited the highest vitamin $\mathrm{E}$ content. The scope of

\subsection{Textural properties}

Our study determined, for the first time, the textural traits (tenderness, hardness, elasticity, cohesiveness, gumminess, chewiness) of different cuts of Subei lamp. The values of six traits were listed in Table 3 . Significant difference was found in textural properties of different cuts of Subei lamp. Tenderness was significantly higher in leg-chump off. Hardness ranged from 1.12 to $43.57 \mathrm{~N}$. Breast and flap exhibited the lowest hardness, followed by shoulder rack French and topside. Square cut shoulder presented the highest cohesive force and gumminess. Previous study reported that the increased hardness with protein addition is desirable because it is an important textural attribute in the determination of acceptable meat product with a fine and mushy consistency ${ }^{[15]}$.

Table 3. Texture properties of nine cuts of Subei lamp

\begin{tabular}{|c|c|c|c|c|c|c|}
\hline Cuts & Tenderness & $\begin{array}{l}\text { Hardness } \\
\left(\mathrm{N} / \mathrm{cm}^{2}\right)\end{array}$ & $\begin{array}{l}\text { Elasticity } \\
(\mathrm{mm})\end{array}$ & $\begin{array}{l}\text { Cohesive } \\
\text { force (ratio) }\end{array}$ & $\begin{array}{l}\text { Gumminess } \\
\left(\mathrm{N} / \mathrm{cm}^{2}\right)\end{array}$ & $\begin{array}{l}\text { Chewiness } \\
(\mathrm{N} / \mathrm{cm})\end{array}$ \\
\hline Square cut shoulder & $1.83^{\mathrm{f}}$ & $29.00^{\mathrm{b}}$ & $5.58^{\mathrm{bc}}$ & $0.74^{\mathrm{a}}$ & $6.16^{\mathrm{a}}$ & $24.35^{\mathrm{bc}}$ \\
\hline Breast and flap & $1.06^{\mathrm{g}}$ & $3.10^{\mathrm{e}}$ & $4.55^{\mathrm{cde}}$ & $0.37^{\mathrm{bc}}$ & $1.07^{\mathrm{c}}$ & $2.60^{\mathrm{d}}$ \\
\hline Topside & $0.90^{\mathrm{h}}$ & $12.99^{\text {de }}$ & $4.43^{\text {cde }}$ & $0.26^{\mathrm{c}}$ & $3.33^{\mathrm{abc}}$ & $15.14^{\mathrm{cd}}$ \\
\hline Tripe & - & $1.12^{\mathrm{e}}$ & $7.95^{\mathrm{a}}$ & $0.57^{\mathrm{ab}}$ & $0.63^{c}$ & $4.67^{\mathrm{d}}$ \\
\hline Neck & $2.16^{\mathrm{e}}$ & $27.19^{b c}$ & $5.12^{\text {bcd }}$ & $0.29^{\mathrm{bc}}$ & $6.41^{\mathrm{a}}$ & $35.20^{\mathrm{ab}}$ \\
\hline Tender loin & $3.23^{\mathrm{b}}$ & $15.61^{\mathrm{cd}}$ & $4.54^{\text {cde }}$ & $0.32^{\mathrm{bc}}$ & $2.01^{\mathrm{bc}}$ & $8.62^{\mathrm{d}}$ \\
\hline Short loin chop & $2.92^{c}$ & $43.57^{\mathrm{a}}$ & $3.37^{\mathrm{e}}$ & $0.26^{\mathrm{c}}$ & $4.22^{\mathrm{abc}}$ & $13.00^{\mathrm{cd}}$ \\
\hline Shoulder rack French & $2.72^{\mathrm{d}}$ & $10.64^{\mathrm{de}}$ & $3.50^{\text {de }}$ & $0.28^{\mathrm{bc}}$ & $2.60^{\mathrm{abc}}$ & $8.83^{\mathrm{d}}$ \\
\hline Leg-chump off & $4.83^{\mathrm{a}}$ & $19.83^{\mathrm{bcd}}$ & $6.26^{b}$ & $0.31^{\mathrm{bc}}$ & $6.04^{\mathrm{ab}}$ & $38.09^{\mathrm{a}}$ \\
\hline
\end{tabular}




\section{Conclusion}

The Subei lamp samples in this study showed considerable variability in levels of nutritional profile and textural properties. The nutrient values of cooked lamp are useful to the consumers than raw values. However, raw values are used to evaluate production and marketing effects on nutrient composition. Like any other foods, these products should be judged in the context of a balanced diet and in appropriate quantities. And in that context it is essential to keep in mind that foods today not only supply the organism's basic nutritional needs but also perform a key function in consumers' quality of life.

\section{Acknowledgement}

This study was supported by the research grant of "The assessment of nutritional profile of Subei lamp". We also wish to thank Qilianmuchang Co., Ltd.

\section{References:}

1. S. Sun, B. Guo, Y. Wei, et al. Food Chem, 124(2011).

2. J. D. Higgs. Trends Food Sci Tech, 11(2000).

3. C. S. Williamson, R. K. Foster, S. A. Stanner, et al. Nutrition Bulletin, 30(2005).

4. C. Motta, I. Castanheira, G. B. Gonzales, et al. J Food Compos Anal, 76(2019).

5. D. W. F. J D Mcgarry. J Lipid Res, 17(1976).

6. S. Galland, F. Le Borgne, D. Guyonnet, et al. Mol cell Biochem, 178(1998).

7. E. Katsanidis, P. B. Addis. Free Radical Bio Med, 27(1999).

8. D. A. Neves, K. B. D. S. Lobato, R. S. Angelica, et al. J Food Compos Anal, 84(2019).

9. R. Ferrari, E. Merli, G. Cicchitelli, et al. Therapeutic Effects of 1-Carnitine and Propionyl-1carnitine on Cardiovascular Diseases: A Review(2004).

10. J. Pekala, B. Patkowska-Sokola, R. Bodkowski, et al. Curr Drug Metab, 12(2011).

11. R. Lango, R. T. Smolenski, M. Narkiewicz, et al. Cardiovasc Res, 51(2001).

12. F. Jiménez-Colmenero, T. Pintado, S. Cofrades, et al. Food Res Int, 43(2010).

13. G. Baldi, S. S. Chauhan, N. Linden, et al. Meat Sci, 148(2019).

14. C. Arzeni, A. M. R. Pilosof. LWT, 111(2019).

15. M. Q. D. Freitas, T. J. P. D. Silva, S. B. Mano, et al. Artigo em Português, 126(2004). 